\title{
Measurement of Human Proinsulin by an Indirect Two-Site Immunoradiometric Assay
}

\author{
S. J. Rainbow ${ }^{1}$, J. S. Woodhead ${ }^{1}$, D. K. Yue ${ }^{2}$, S. D. Luzio ${ }^{3}$, and C. N. Hales ${ }^{3}$ \\ ${ }^{1}$ Department of Medical Biochemistry, Welsh National School of Medicine, Cardiff, Wales, and ${ }^{3}$ Department of Clinical Biochermistry, \\ University of Cambridge, Addenbrooke's Hospital, Cambridge, England
}

\begin{abstract}
Summary. An indirect two-site immunoradiometric assay is described for the measurement of human proinsulin in plasma. Polyethylene tubes coated with purified guinea-pig antibodies to insulin were used to extract proinsulin and insulin from plasma. Rabbit antibody to human $\mathrm{C}$ peptide was then added to react with the C-peptide moiety of the bound proinsulin. The uptake of this antibody was measured by the subsequent binding of ${ }^{125}$ I-sheep antibody to rabbit IgG. The binding of radioactivity to the tubes was a function of the proinsulin concentration in the sample. The sensitivity of the assay was $0.006 \mathrm{pmol} / \mathrm{ml}$. Only $200 \mu$ of plasma was required in the assay and the ${ }^{125}$ I-labelled antibody was produced from readily available reagents. The polyethylene tubes remained stable for at least 5 months after coating. The mean fasting proinsulin level was $0.009 \mathrm{pmol} / \mathrm{ml}$ in sixteen normal subjects and $0.025 \mathrm{pmol} / \mathrm{ml}$ in twelve maturity onset diabetics. Oral glucose produced an 8 fold increase in proinsulin concentration but a decline in the plasma proinsulin/insulin molar ratio. Four patients with insulinoma had extremely elevated proinsulin levels and proinsulin/insulin ratios.
\end{abstract}

Key words: Indirect two-site immunoradiometric assay, human proinsulin, insulin, C-peptide, diabetes, insulinoma.

Since the discovery of proinsulin [1] many attempts have been made to measure this prohormone in plasma as a means of assessing $\beta$ cell function. Direct radioimmunoassay is not possible since antibodies

\footnotetext{
2 Present address: Department of Medicine, The University of Sydney, Sydney, N.S.W., Australia 2006
}

raised against proinsulin cross-react with insulin and C-peptide [2]. Gel filtration [3] and an insulin degrading enzyme [4] have been used to remove these interfering substances before assay, but these methods are either laborious or non-specific [2, 5]. A technique has been described recently in which insulin and proinsulin are extracted from plasma by means of an insulin antibody immunoadsorbent. The proinsulin is then measured by radioimmunoassay of the C-peptide moiety of the extracted proinsulin [6].

We previously described an immunoassay which used antibodies to extract antigen onto a solid phase [7]. This was followed by measurement of the bound antigen by reaction with a second labelled antibody. This was termed a two-site assay to emphasize its property of recognizing simultaneously two separate antigenic sites on a single molecule. This procedure was subsequently made more economical in the use of reagents by the use of labelled species specific antibody to IgG to detect the uptake of the second antibody and hence to measure indirectly the amount of bound antigen [8]. We report here an adaptation of this method for the development of a sensitive indirect two-site immunoradiometric assay for the measurement of human proinsulin in plasma. Proinsulin is recognised as a molecule possessing both insulin and C-peptide antigenic sites. The binding of the C-peptide segment of proinsulin with a rabbit antibody to $\mathrm{C}$-peptide is measured by the subsequent binding of ${ }^{125} \mathrm{I}$-sheep antibody to rabbit IgG.

\section{Materials and Methods}

\section{Proinsulin}

Human proinsulin was provided by Dr. A. Rubenstein of The University of Chicago, Chicago, Illinois. Porcine and bovine proinsulins were gifts from Dr. R. Chance of the Eli Lilly Research 


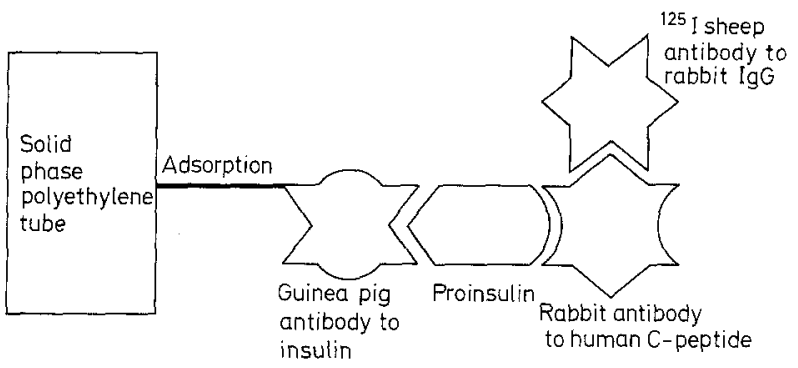

Fig. 1. Principle of the indirect two-site immunoradiometric assay for proinsulin

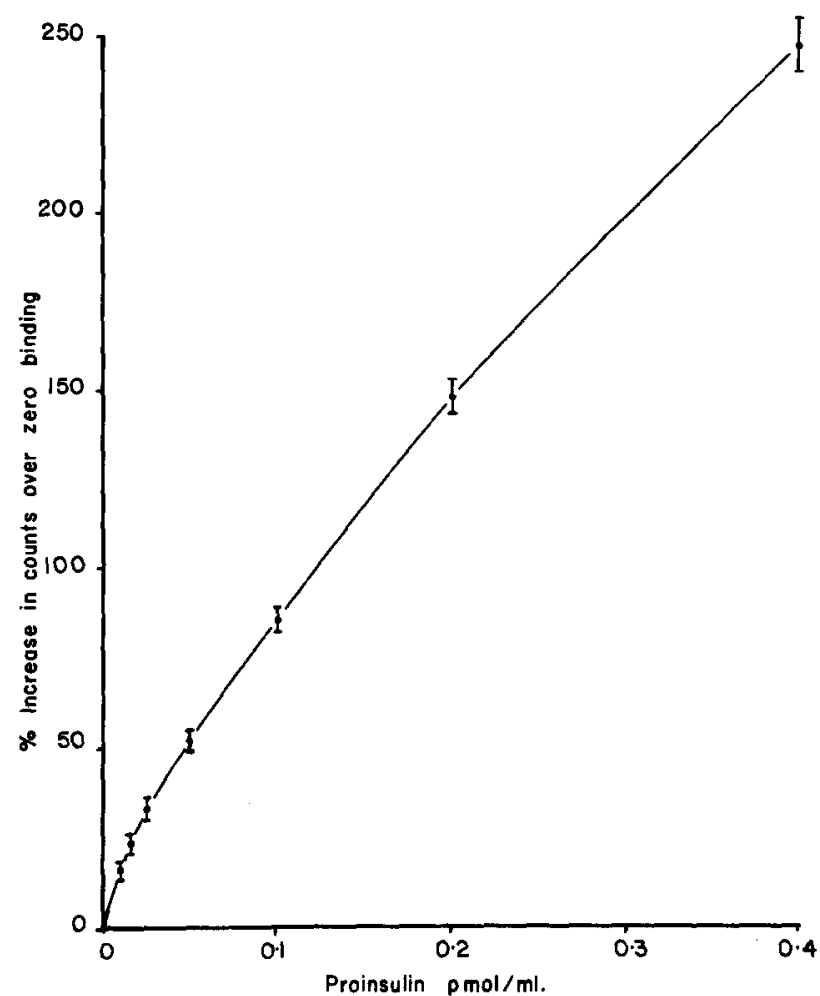

Fig. 2. The mean \pm SEM of 10 human proinsulin standard curves. Binding capacity of tubes 1.33 pmol, rabbit antibody to human C-peptide diluted $1 / 1000$

Laboratories, Indianapolis, Indiana. A partially purified laboratory proinsulin standard was prepared from an acid ethanol extract of human pancreas by the method of Davoren [9]. The extract was chromatographed on a Sephadex $G 50$ column $(85 \times 1.5 \mathrm{~cm})$ and eluted with acetic acid $(1 \mathrm{~mol} / \mathrm{l})$. Fractions from the column were assayed for insulin, C-peptide and proinsulin immunoreactivity after dialysis against phosphate-buffered saline (PBS) containing $\mathrm{NaH}_{2} \mathrm{Po}_{4} / \mathrm{Na}_{2} \mathrm{HPO}_{4} 0.05 \mathrm{~mol} / \mathrm{l}, \mathrm{NaCl} 0.15 \mathrm{~mol} / \mathrm{l}, \mathrm{p} 7.4$. Three peaks of insulin immunoreactivity were recognised. The second peak eluted at the position of porcine proinsulin and also contained C-peptide and proinsulin immunoreactivity. Fractions from this peak were pooled and calibrated against the purified human proinsulin standard. Aliquots were stored at $-20^{\circ} \mathrm{C}$ in PBS with added human serum albumin $(10 \mathrm{~g} / 1)$. This preparation diluted in parallel with the pure proinsulin in the indirect two-site immunoradiometric assay.

\section{Preparation of Immunoadsorbents}

Immunoadsorbents were prepared by reacting proteins in borate buffer (boric acid $0.2 \mathrm{~mol} / 1$, potassium chloride $0.2 \mathrm{~mol} / 1, \mathrm{pH} 8.2$ ) with a diazonium salt of powdered celluluse (CC 41 from Whatman Biochemicals Ltd., Springfield Mill, Maidstone, Kent, U.K.) using a procedure described previously [10]. Equal weights of rabbit IgG (Koch-Light Laboratories Ltd., Colnbrook, Bucks, U.K.) and diazocellulose were reacted at $4{ }^{\circ} \mathrm{C}$ for 48 hours. Insulin antibody immunoadsorbent was prepared by an identical procedure using an IgG fraction of guinea-pig anti-insulin serum prepared by sodium sulphate precipitation [11]. Insulin immunoadsorbent was prepared by reacting $10 \mathrm{mg}$ bovine insulin (Sigma Chemical Co. Ltd., London, U.K.) with $50 \mathrm{mg}$ diazocellulose. The protein uptake, assessed by the method of Lowry [12], ranged from $120-350 \mu \mathrm{g} / \mathrm{mg}$ cellulose. The immunoadsorbents were stored at $4^{\circ} \mathrm{C}$ at a concentration of $1 \mathrm{mg}$ cellulose $/ \mathrm{ml}$ in a buffer containing sodium barbitone $0.05 \mathrm{~mol} / 1$, sodium chloride $0.17 \mathrm{~mol} / 1$, human serum albumin $1 \mathrm{~g} / \mathrm{l}$, sodium azide $200 \mathrm{mg} / 1$ and non-immune guinea-pig $\operatorname{IgG} 20 \mathrm{mg} / \mathrm{l}$, pH 8.0 (NIGP Buffer). Before use a suitable quantity of the immunoadsorbent was washed three times with $2 \mathrm{ml}$ of NIGP buffer and centrifuged at $300 \mathrm{~g}$ for $2 \mathrm{~min}$ after each wash.

\section{Antisera}

Rabbit antiserum (K5) and guinea-pig antiserum (M1187) to human C-peptide were gifts from Dr. L. G. Heding of the Novo Research Institute, Copenhagen. Antisera to insulin were raised in guinea-pigs by multiple site intradermal injections of bovine insulin in Freund's adjuvant at one monthly intervals. Animals were bled 10 days following booster injections. Antisera to rabbit IgG were raised in a sheep by an identical procedure.

\section{Preparation of ${ }^{125}$ I-Sheep Antibody to Rabbit IgG}

Sheep antisera to rabbit IgG ( $400 \mu \mathrm{l})$ were incubated with rabbit IgG immunoadsorbent (50 $\mu \mathrm{g}$ cellulose base) for 24 hours at $4^{\circ} \mathrm{C}$. The immunoadsorbent was then washed four times in phosphate buffer $\left(\mathrm{NaH}_{2} \mathrm{PO}_{4} / \mathrm{Na}_{2} \mathrm{HPO}_{4} 0.5 \mathrm{~mol} / \mathrm{l}, \mathrm{pH} 7.4\right)$ and suspended in $10 \mu \mathrm{l}$ of the same buffer. Iodination was carried out by the addition of $1 \mathrm{mCi} \mathrm{Na}{ }^{125}$ I (Radiochemical Centre, Amersham, Bucks., U.K.) followed by $25 \mu \mathrm{g}$ chloramine-T in $10 \mu \mathrm{l}$ phosphate buffer. The reaction was stopped after 15 seconds by addition of $60 \mu \mathrm{g}$ sodium metabisulphate in $10 \mu \mathrm{l}$ phosphate buffer. The mixture was transferred to a filter funnel lined with a single layer of No. 41 filter paper (Whatman Biochemicals Ltd., Springfield Mill, Maidstone, Kent, U.K.) and washed with $200 \mathrm{ml}$ of NIGP buffer. Low affinity antibodies were removed by washing with $100 \mathrm{ml}$ of $0.001 \mathrm{~mol} / \mathrm{lHCl}(\mathrm{pH} 3)$. High affinity antibodies were eluted with $4 \mathrm{ml}$ of $0.01 \mathrm{~mol} / \mathrm{lHCl}(\mathrm{pH} 2)$ into an equal volume of double strength NIGP buffer. Approximately $20 \%$ of the eluted radioactivity resided in the $\mathrm{pH} 2$ fraction. Rabbit $\mathrm{IgG}$ immunoadsorbent $(1 \mathrm{mg})$ was added to the $\mathrm{pH} 2$ fraction and the mixture stored at $4^{\circ} \mathrm{C}$. When required the ${ }^{125}$ I-sheep antibody to rabbit IgG was eluted from an aliquot of the immunoadorbent by washing sequentially with $25 \mathrm{ml} \mathrm{NIGP} \mathrm{buffer,} 10 \mathrm{ml} 0.001 \mathrm{~mol} / \mathrm{lHCl}(\mathrm{pH} 3)$ and $2 \mathrm{ml} 0.01 \mathrm{~mol} / \mathrm{LHCl}$ ( $\mathrm{pH} 2$ ). The $\mathrm{pH} 2$ wash, containing approximately $50 \%$ of the radioactivity, was collected into an equal volume of double strength NIGP buffer and used in the two-site immunoradiometric assay.

\section{Preparation of Antibody-Coated Tubes}

Purified insulin antibodies were prepared by reacting $10 \mathrm{ml}$ of guinea-pig anti-insulin serum (binding capacity $1-2 \mathrm{u} / \mathrm{ml}$ insulin) 
with insulin immunoadsorbent ( $20 \mathrm{mg}$ cellulose base) for 24 hours at $4^{\circ} \mathrm{C}$ on a rotating turntable. After centrifugation, the pellet was transferred to a funnel lined with filter paper and washed with $100 \mathrm{ml} \mathrm{NIGP}$ buffer, $50 \mathrm{ml} 0.001 \mathrm{~mol} / \mathrm{lHCl}(\mathrm{pH} 3)$ and $5 \mathrm{ml}$ $0.01 \mathrm{~mol} / \mathrm{lHCl}(\mathrm{pH} 2)$. The $\mathrm{pH} 2$ eluate was collected into $0.3 \mathrm{ml}$ sodium carbonate $(0.1 \mathrm{~mol} / \mathrm{l})$ in a glass container and diluted to a volume of $50 \mathrm{ml}$ with sodium hydrogen carbonate buffer $(0.05 \mathrm{~mol} / 1, \mathrm{pH}$ adjusted to 9.6) [13]. Polyethylene tubes (No. 700 from Sarstedt Laboratory, West Germany) were coated by the addition of $200 \mu \mathrm{l}$ of this purified insulin antibody solution. After 24 hours at room temperature, the antibody solution was aspirated, unadsorbed protein was removed by washing three times with a solution containing sodium chloride $0.15 \mathrm{~mol} / \mathrm{l}$, bovine serum albumin $5 \mathrm{~g} / \mathrm{l}$, merthiolate $0.1 \mathrm{~g} / 1$. After the initial coating the purified antibody solution was concentrated to $50 \%$ of its original volume by dialysis against a $15 \%(\mathrm{w} / \mathrm{v})$ solution of Carbowax (Hopkin \& Williams, Chadwell Heath, Essex, U.K.). This could then be reused for coating a second batch of tubes. Different batches of tubes were always stored separately at $-20^{\circ} \mathrm{C}$ and used in different assays.

The insulin binding capacity of the tubes was studied at different insulin concentrations $(0.06-30 \mathrm{pmol} / \mathrm{ml})$ and results evaluated by Scatchard Analysis [14]. Tubes tested up to 5 months after coating showed no deterioration in binding capacity.

\section{Assay Procedure for Proinsulin}

The principle of the assay procedure is illustrated in Fig. 1. Tubes coated with purified insulin antibody were used to extract proinsulin and insulin from plasma. After washing to remove other plasma proteins including $\mathrm{C}$-peptide, the solid phase complex was reacted with rabbit antibodies to human $\mathrm{C}$-peptide and washed again. The uptake of the rabbit antibodies on to the proinsulin was measured by reaction with ${ }^{125} \mathrm{I}$-sheep antibodies to rabbit IgG. The uptake of label was a function of the concentration of proinsulin in the plasma.

Proinsulin standards were made up in plasma prepared by extracting normal human fasting plasma $(1 \mathrm{ml})$ with insulin antibody immunoadsorbent $\left(3 \mathrm{mg}\right.$ ) for 24 hours at $4^{\circ} \mathrm{C}$ on a rotating turntable. Human proinsulin $(0.2 \mathrm{pmol})$ added to plasma $(1 \mathrm{ml})$ was completely removed by immunoadsorbent treatment in this manner. The effectiveness of extraction was also demonstrated by the removal of ${ }^{125}$ I-insulin and insulin as measured by radioimmunoassay. Standards or samples in $200 \mu \mathrm{l}$ were added in triplicate to antibody-coated tubes. After incubation at $4^{\circ} \mathrm{C}$ for 24 hours unreacted protein was removed by washing twice with $400 \mu \mathrm{l}$ of NIGP buffer. Rabbit antibody to human C-peptide diluted in PBS was then added. Following a further 24 hours incubation at $4^{\circ} \mathrm{C}$ and two washes with $400 \mu \mathrm{l}$ NIGP buffer, $200 \mu \mathrm{l}{ }^{125}$ I-sheep antibody to rabbit IgG was added in PBS. After 24 hours at $4^{\circ} \mathrm{C}$ the tubes were washed twice with NIGP buffer and counted in a Wallac Decem automatic gamma counter.

\section{Insulin, C-Peptide and Glucose Measurement}

Insulin and C-peptide were measured by conventional radioimmunoassay $[15,16]$. Glucose was measured by a standard autoanalyser technique using glucose oxidase.

\section{Plasma Samples}

Fasting plasma samples were obtained from 16 normal subjects (15 males, 1 female, mean age $30 \pm 3$ years, $102 \pm 3 \%$ ideal body weight), 12 patients with maturity onset diabetes $(9$ males, 3 females, mean age $63 \pm 3$ years, $117 \pm 3 \%$ ideal body weight, 6 treated with diet alone, 6 with diet and a sulphonylurea, mean
Table 1. Recovery of proinsulin at various insulin concentrations using antibody-coated tubes of different insulin binding capacity

\begin{tabular}{llrl}
\hline $\begin{array}{l}\text { Insulin con- } \\
\text { centration in } \\
200 \mu \mathrm{lsample} \\
(\mathrm{pmol} / \mathrm{ml})\end{array}$ & $\begin{array}{l}\text { Recovery of added proinsulin }(0.1 \mathrm{pmol} / \mathrm{ml}) \mathrm{using} \\
\text { antibody-coated tubes of different insulin binding } \\
\text { capacity }(\%)\end{array}$ \\
\cline { 2 - 3 } & $\begin{array}{l}\text { Binding } \\
\text { capacity }\end{array}$ & & \\
& 2 pmol/tube & $1.33 \mathrm{pmol} /$ tube & $0.67 \mathrm{pmol} /$ tube \\
\hline 2.67 & 90 & 54 & 50 \\
1.33 & 100 & 94 & 64 \\
0.67 & 100 & 100 & 78 \\
0.33 & 100 & 100 & 96
\end{tabular}

a The actual amount of insulin present in the assay tube in $\mathrm{p} / \mathrm{mol}$ was $1 / 5$ of this figure

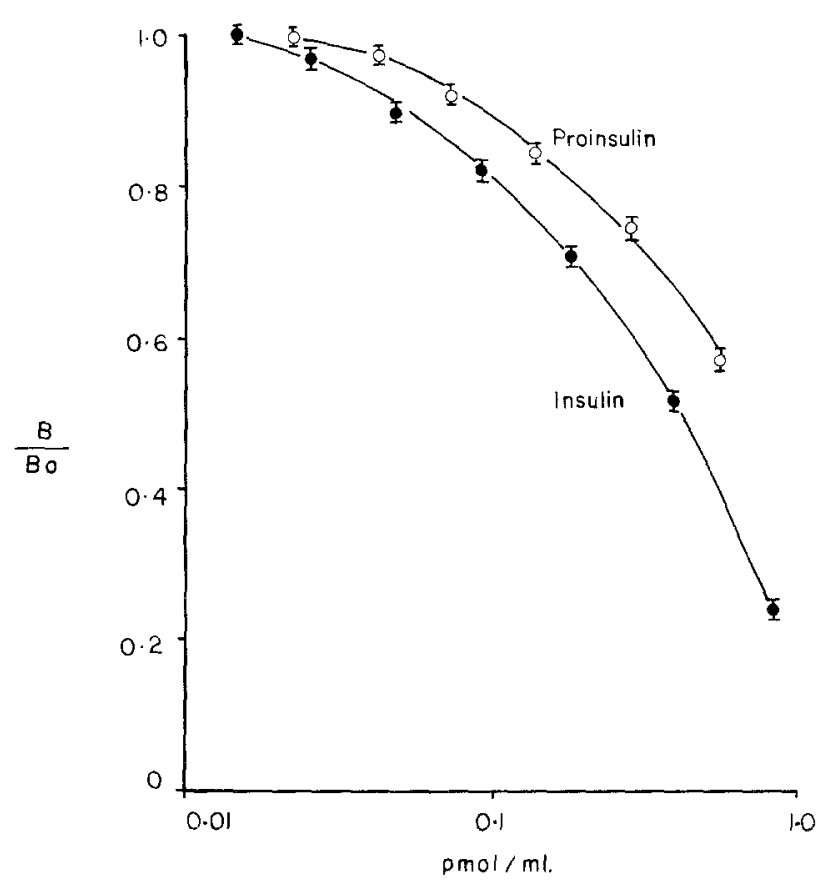

Fig. 3. The immunoreactivity of proinsulin in the insulin radioimmunoassay. $B_{0}$ is the radioactivity bound in the absence of antigen, $B$ is the radioactivity bound in the presence of antigen. $n=4$

duration of diabetes 4 years) and 4 patients ( 2 male, 2 female) with surgically proven insulinoma. Additional specimens were obtained from 8 of these normal subjects ( 7 males, 1 female) before and during a $50 \mathrm{~g}$ oral glucose tolerance test at times $-10,0,+10,30$, $50,70,110,120$ minutes.

Specimens were collected into heparinised tubes and plasma was separated by centrifugation and stored at $-20^{\circ} \mathrm{C}$ until studied.

\section{Results}

The mean dose response curve of 10 human proinsulin assays using 5 batches of ${ }^{125}$ I-sheep antibody to 
Table 2. Fasting proinsulin, insulin, proinsulin/insulin ratio and glucose levels in normal and maturity onset diabetic subjects

\begin{tabular}{llllll}
\hline Group & & $\begin{array}{l}\text { Proinsulin } \\
\text { pmol/ml }\end{array}$ & $\begin{array}{l}\text { Insulin } \\
\text { pmol/ml }\end{array}$ & $\begin{array}{l}\text { Proinsulin } \\
\text { Insulin }\end{array}$ & $\begin{array}{l}\text { Glucose } \\
\text { mmol/1 }\end{array}$ \\
\hline Normal subjects & Mean & 0.009 & 0.043 & 0.33 & 4.1 \\
$(\mathrm{n}=16)$ & SEM & 0.002 & 0.005 & 0.09 & 0.1 \\
& Range & $0-0.022$ & $0.025-0.083$ & $0.03-1.25$ & $3.2-5.0$ \\
Maturity-onset diabetics & Mean & 0.025 & $0.066^{\mathrm{a}}$ & 0.80 & 7.7 \\
$(\mathrm{n}=12)$ & SEM & 0.012 & 0.011 & 0.32 & 0.7 \\
& Range & $0-0.104$ & $0.025-0.092$ & $0.04-3.35$ & $4.5-12.3$ \\
\end{tabular}

a Significantly higher than normal controls $\mathrm{P}<0.05$ (Wilcoxon's rank sum test)
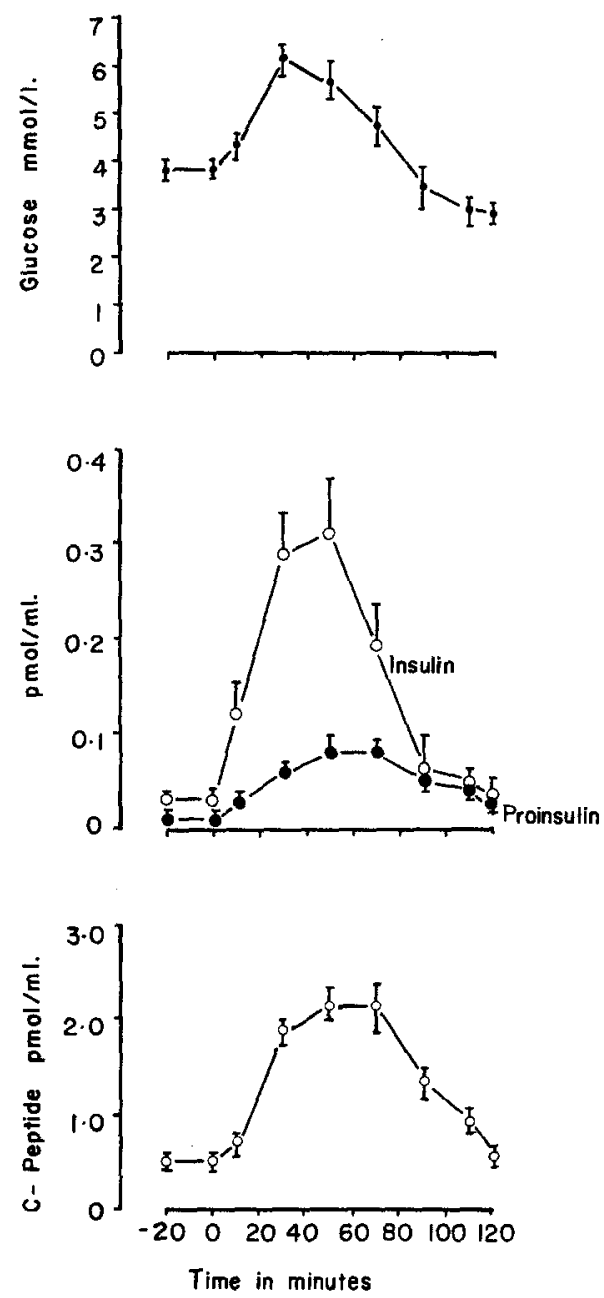

Fig. 4. The mean \pm SEM of glucose, insulin, proinsulin and Cpeptide responses during oral glucose tolerance tests in 8 normal subjects

rabbit $\operatorname{IgG}$ is shown in Fig. 2. The detection limit of the assay, defined as the minimal proinsulin concentration which produced a radioactivity uptake on to the tubes, more than 2 standard deviations from the non-specific binding was $0.006 \mathrm{pmol} / \mathrm{ml}$. The interassay coefficient of variation was $7 \%$.

Increasing the concentration of rabbit antibody to human C-peptide from $1 / 1000$ to $1 / 250$ produced an increase in non-specific binding with no appreciable change in sensitivity. However, when the antiserum was used in a dilution of $1 / 2000$ there was a loss of steepness of the standard curve at proinsulin concentrations greater than $0.2 \mathrm{pmol} / \mathrm{ml}$. A dilution of $1 / 1000$ was used routinely in all assays. The effect of varying the amount of ${ }^{125} \mathrm{I}$-sheep antibody to rabbit IgG was tested over a 30 fold range from 500 c.p.m. to 150000 c.p.m. With increasing amounts of label there was a progressive decline in the percentage of radioactivity bound non-specifically. There was no significant change in sensitivity. In practice a total radioactivity of 10000-20000 c.p.m. per tube was found to be convenient. Under the experimental conditions described the non-specific binding was between $6-9 \%$.

\section{Recovery of Proinsulin}

Insulin and proinsulin binding capacity of the coated tubes varied directly with the concentrations of purified insulin antibodies applied for coating. Tubes with insulin binding capacity of $0.66,1.33$ and $2 \mathrm{pmol} /$ tube yielded essentially superimposable standard curves. However, the recoveries of added proinsulin concentrations (tested at $0.1 \mathrm{pmol} / \mathrm{ml}$ ) were dramatically different. The results shown in Table 1 are typical and reproducible. For the measurement of human proinsulin in plasma, coated-tubes with an insulin binding capacity of $1.33 \mathrm{pmol} /$ tube were used. Specimens with insulin immunoreactivity greater than $200 \mu \mathrm{U} / \mathrm{ml}$ were diluted to less than this level before assay.

\section{Specificity}

Serial dilutions of plasma from a patient with an insulinoma showed a response parallel to the proinsulin standard curve (data not shown). Human Cpeptide $(5 \mathrm{pmol} / \mathrm{ml})$, bovine insulin $(0.75 \mathrm{pmol} / \mathrm{ml})$, porcine proinsulin $(1.37 \mathrm{pmol} / \mathrm{ml})$ and bovine proinsulin $(1.37 \mathrm{pmol} / \mathrm{ml})$ were not detectable in this assay. 


\section{Immunoreactivity of Human Proinsulin in the Insulin Assay}

The immunoreactivity of proinsulin in the insulin radioimmunoassay is shown in Fig. 3 . On a molar basis proinsulin was $50.7 \pm 1.3 \%$ as reactive as insulin in concentrations of up to $0.6 \mathrm{pmol} / \mathrm{ml}$. The insulin content of each sample was derived by subtracting $50 \%$ of the measured proinsulin value from the insulin immunoreactivity. The proinsulin/insulin molar ratio of each sample was calculated accordingly.

\section{Proinsulin Concentrations in Human Plasma}

Fasting concentrations of proinsulin, insulin and glucose in normal subjects and patients with maturity onset diabetes are shown in Table 2. The insulin concentrations were significantly higher in the maturity onset diabetic subjects than in the normal controls $(\mathrm{P}<0.05)$. The mean proinsulin concentration and proinsulin/insulin ratio were also elevated in these diabetic patients. However, due to the wide scatter of individual results this did not reach significance at the $5 \%$ level. No correlation was found between body weight and proinsulin concentration.

The proinsulin, insulin, C-peptide and glucose responses of normal individuals during oral glucose tolerance tests are shown in Fig. 4. There was a 10 fold increase in insulin concentrations whilst the proinsulin levels rose 8 fold. In comparison with insulin and C-peptide the changes in proinsulin concentration followed a slower time course. The mean proinsulin/insulin ratio fell from 0.40 initially to a minimum or 0.20 at thirty minutes. The ratio the increased progressively to 1.0 at 90 minutes and declined almost to the basal level at 120 minutes.

Results from four patients with insulinomata are shown in Table 3. In all patients the proinsulin concentrations were greatly elevated, showing no overlap with the normal controls. The mean proinsulin concentration was 5 fold higher than that from nor$\mathrm{mal}$ individuals. The proinsulin/insulin ratio accentuated this difference; being 18 fold higher in the insulinoma patients.

\section{Discussion}

The two-site indirect immunoradiometric assay described in this study measures proinsulin by recognising it as a molecule with both an insulin and a $\mathrm{C}$ peptide immunogenic site. This confers a high degree of specificity, thus making a preliminary elimination of insulin and C-peptide unnecessary. This specificity is demonstrated by the observation that human Cpeptide, bovine insulin, bovine proinsulin and por-
Table 3. Fasting proinsulin, insulin, proinsulin/insulin ratio and glucose levels in patients with insulinoma

\begin{tabular}{lllll}
\hline Patient & $\begin{array}{l}\text { Proinsulin } \\
\text { pmol/ml }\end{array}$ & $\begin{array}{l}\text { Insulin } \\
\text { pmol/ml }\end{array}$ & $\begin{array}{l}\text { Proinsulin } \\
\text { Insulin }\end{array}$ & $\begin{array}{l}\text { Glucose } \\
\mathrm{mmol} / \mathrm{l}\end{array}$ \\
\hline I & 0.18 & 0.13 & 4.5 & 2.1 \\
II & 0.23 & 0.18 & 3.5 & 3.6 \\
III & 1.22 & 0.81 & 6.1 & 1.2 \\
IV & 0.25 & 0.15 & 10.0 & 2.4 \\
\hline Mean & 0.47 & 0.32 & 6.0 & 2.3 \\
SEM & 0.25 & 0.16 & 1.4 & 0.5 \\
\hline
\end{tabular}

cine proinsulin, in high concentrations did not react in this system. The principle of using two antibodies in the measurement of a substance has been employed previously [7]. Intact parathyroid hormone [17] can be measured, in the presence of circulating fragments, using two antibodies directed against different terminals of the molecule. A two-site radioimmunoassay for proinsulin has been described by Heding [6]. The sensitivity of the two-site radioimmunoassay and the two-site immunoradiometric assay described here are similar and results obtained with these procedures in good agreement. In the immunoradiometric assay a smaller volume of sample was employed. The preparation of iodinated tyrosylated C-peptide is not necessary. These advantages enable the immunoradiometric technique to be more readily adaptable for the measurement of proinsulin of other animal species by using different rabbit antibody to C-peptide [18].

The polyethylene tubes used in this method are easy to handle in large numbers and remain stable over a prolonged period after coating. The adsorption of purified insulin antibodies on to these tubes and the insulin binding capacity of each batch of tubes may be adjusted by simply altering the concentrations of purified insulin antibody used. As plasma insulin and proinsulin, present approximately in a molar ratio of $5: 1[2,19]$, compete for the guinea-pig insulin antibodies on the coated tubes it is essential that the tubes should have an insulin binding capacity significantly in excess of the total insulin and proinsulin in the sample. The fulfilment of this requirement was demonstrated by two means. Firstly, the insulin binding of the tubes was studied at different insulin concentrations and the results evaluated by Scatchard Analysis. Secondly, a known amount of proinsulin was measured at different insulin concentrations to ensure adequate recovery. In practice, it was found that an insulin binding capacity 5 fold in excess of the insulin in the sample was satisfactory.

This proinsulin assay measures molecules with $\mathrm{C}$ peptide and insulin immunoreactivity, it is thus pos- 
sible that it may not distinguish proinsulin from proinsulin-insulin intermediates. Until these intermediates are available in pure form, it is not possible to assess their reactivity in this assay. To measure proinsulin in the presence of insulin or proinsulin antibodies it would be first necessary to carry out a separation procedure. The findings of the proinsulin/ insulin ratio in the fasting state in normal individuals are in general agreement with those of the enzyme method [4] and the specific radioimmunoassay [6]. These assays tend to give a slightly higher fasting ratio than the column method $[19,20]$. Both the specific radioimmunoassay [6] and this immunoradiometric assay have the advantage of measuring proinsulin plasma containing less than $30 \mu \mathrm{u} / \mathrm{ml}$ $(0.2 \mathrm{pmol} / \mathrm{ml})$ of immunoreactive insulin. No clear relationships emerged between body weight and proinsulin concentration but our samples were too small in number for definite conclusions. The elevated proinsulin levels in patients with an insulinoma confirm the usefulness of proinsulin measurement in the differential diagnosis of hypoglycaemia $[21,22$, 23].

Acknowledgements. We wish to thank the physicians of the University Hospital of Wales for their co-operation in this study; Dr. A. Rubenstein for the human proinsulin; Dr. R. Chance for the bovine and porcine proinsulin; and Dr. Lise Heading for the anti-C-peptide sera. D. K. Yue was supported by the Coppleson Postgraduate Medical Foundation of N.S.W.: The Beecham Travelling Fellowship of the Royal Australasian College of Physicians; The Nuffield Foundation and the Susman Bequest of the University of Sydney. S.D. Luzio was supported by Dr. Karl Thomae $\mathrm{GmbH}$, Biberach an der Riss. We are grateful to Dr. Owain Gibby for his many helpful comments and to Mrs. Lee Creswell and Mrs. Phyllis Brown for their secretarial assistance. Financial support was received from the British Diabetic Association for this work.

\section{References}

1. Steiner, D. F., Cunningham, D., Spigelman, L., Aten, B.: Insulin biosynthesis - Evidence for a precursor. Science 157, 697-700 (1967)

2. Rubenstein, A.H., Melani, F., Steiner, D. F.: Circulating proinsulin: immunology, measurement, and biological activity. In: Handbook of physiology, endocrinology. I. Steiner D. F., Freinkel N. (Eds.), pp 515-528. Baltimore: Williams and Wilkins 1972

3. Melani, F., Rubenstein, A.H., Oyer, P. E., Steiner, D. F.: Identification of proinsulin and C-peptide in human serum by a specific immunoassay. Proc. Natl. Acad. Sci. USA 67, 148-155 (1970)

4. Kitabchi, A. E., Duckworth, W. C., Brush, J. S., Heinemann, M.: Direct measurement of proinsulin in human plasma by the use of an insulin-degrading enzyme. J. Clin. Invest. 50, 1792-1799 (1971)

5. Starr, J. I., Juhn, D. D., Rubenstein, A. H., Kitabchi, A. E.: Degradation of insulin in serum by insulin specific protease. $J$. Lab. Clin. Med. 86, 631-637 (1975)
6. Heding, L.G.: Specific and direct radioimmunoassay for human proinsulin in serum. Diabetologia 13, 464-474 (1977)

7. Addison, G. M., Hales, C. N.: Two site assay of human growth hormone. Horm. Metab. Res. 3, 59-60 (1971)

8. Beck, P., Hales, C. N.: Immunoassay of serum polypeptide hormones by using ${ }^{125}$ I-labelled anti-(Immunoglobulin $\mathrm{G}$ ) antibodies. Biochem. J. 145, 607-616 (1975)

9. Davoren, P. R.: The isolation of insulin from a single cat pancreas. Biochim. Biophys. Acta 63, 150-153 (1962)

10. Addison, G. M., Hales, C.N., Woodhead, J.S., O'Riordan, J. L. H.: Immunoradiometric assay of parathyroid hormone. J. Endocrinol. 49, 521-530 (1971)

11. Deutsch, H.F.: Purification of antibody. In: Methods in immunology and immunochemistry, Vol. I. Williams, C. A., Chase, M.W. (Eds.), pp. 315-321. New York, London: Academic Press 1967

12. Lowry, O. H., Rosebrough, N. J., Farr, A. L., Randall, R. J.: Protein measurement with folin phenol reagent. J. Biol. Chem. 193, 265-275 (1951)

13. Catt, K. J., Tregear, G. W.: Solid-phase radioimmunoassay in antibody coated tubes. Science 158, 1570-1571 (1967)

14. Scatchard, G.: The attraction of proteins for small molecules and ions. Ann. N. Y. Acad. Sci. 51, 660-672 (1949)

15. Hales, C. N., Randle, P. J.: Immunoassay of insulin with insulin - antibody precipitate. Biochem. J. 88, 137-146 (1963)

16. Heding, L. G.: Radioimmunological determination of human C-peptide in serum. Diabetologia 11, 541-548 (1975)

17. Woodhead, J. S., Davies, S. J., Lister, D.: Two-site assay of bovine parathyroid hormone. J. Endocrinol. 73, 279-288 (1977)

18. Yue, D. K., Gibby, O. M., Luzio, S. D., Yanaihara, N., Hales, C. N.: Indirect two-site immunoradiometric assay of rat and mouse proinsulin. Diabetologia 17, 235-242 (1979)

19. Horwitz, D. L., Starr, J. I., Mako, M. E., Blackhard, E. G., Rubenstein, A. H.: Proinsulin, insulin and C-peptide concentrations in human portal and peripheral blood. J. Clin. Invest. 55, 1278-1283 (1975)

20. Duckworth, W. C., Kitabchi, A. E.: Direct measurement of plasma proinsulin in normal and diabetic subjects. Am. J. Med. 53, 418-427 (1972)

21. Gorden, P., Sherman, B., Roth, J.: Proinsulin-like component of circulating insulin in the basal state and in patients and hamsters with islet cell tumours. J. Clin. Invest. 50, 2113-2122 (1971)

22. Alsever, R. N., Roberts, J.P., Gerber, J. G., Mako, M. E., Rubenstein, A.H.: Insulinoma with low circulating insulin levels: The diagnostic value of proinsulin measurements. Ann. Intern. Med. 82, 347-350 (1975)

23. Sherman, B.M., Pek, S., Fajan, S. S., Floyd, J.C. Jr., Ann, F. W.: Plasma proinsulin in patients with functioning pancreatic islet cell tumour. J. Clin. Endocrinol. Metab. 35, 271-280 (1972)

Received: December 18, 1978

and in revised form: June 8, 1979

Prof. C. N. Hales

University of Cambridge

Department of Clinical Biochemistry

Addenbrooke's Hospital

Hills Road

Cambridge CB2 2QR

England 